\title{
Pemanfaatan Sosial Media Sebagai Bentuk Inovasi, Strategi Komunikasi dan Kreatifitas Layanan di Perpustakaan Perguruan Tinggi
}

\author{
RM Endhar Priyo Utomo \\ Perpustakaan Fakultas Ekonomika dan Bisnis Universitas Diponegoro \\ Email : endhar.priyo@gmail.com
}

\begin{abstract}
Social media has more capabilities than other media to help the library in improving the quality of services that will be provided to its users. Social media for users / users also makes it easy to access data or any form of information in the library. Social media for libraries can also encourage librarians to innovate to create new forms of services that have not existed before in the library. Social media can also increase the creativity of a librarian to create new services that have not been in the library before.
\end{abstract}

Keywords: Social Media; Library Service; Innovation; Communication Strategic

\begin{abstract}
Abstrak
Media sosial memiliki kemampuan lebih dari media lain untuk membantu perpustakaan dalam meningkatkan kualitas layanan yang akan diberikan kepada penggunanya. Media sosial untuk pengguna / pengguna juga memudahkan untuk mengakses data atau segala bentuk informasi di perpustakaan. Media sosial untuk perpustakaan juga dapat mendorong pustakawan untuk berinovasi untuk menciptakan bentuk layanan baru yang belum ada sebelumnya di perpustakaan. Media sosial juga dapat meningkatkan kreativitas seorang pustakawan untuk menciptakan layanan baru yang belum ada di perpustakaan sebelumnya.

Kata kunci: Sosial Media; Layanan Perpustakaan; Inovasi; Komunikasi Strategis
\end{abstract}

\section{A. PENDAHULUAN}

Dalam beberapa dekade terakhir ini, telah terjadi banyak perkembangan dalam teknologi dan informasi. Perkembangan ini tidak dapat dihindari dalam berbagai aspek kehidupan, termasuk di dalamnya adalah perpustakaan. Perpustakaan sebagai salah satu penyedia informasi bagi 
penggunanya, haruslah memiliki kesadaran akan adanya perkembangan ini. Terlebih dengan semakin bertumbuhnya tuntutan dari para pemustaka untuk bisa mendapatkan akses terhadap sumber-sumber informasi yang ada di perpustakaan secara lebih cepat.

Perpustakaan sebagai sebuah institusi yang berkembang sebagaimana prinsip dari hukum ketiga dari "Five New Laws of Librarianship" yaitu use technology intellegently to enhance service telah memunculkan sebuah paradigma baru dalam penciptaan bentuk-bentuk layanan yang ada di perpustakaan. Internet sebagai bentuk dari perkembangan teknologi informasi memungkinkan perpustakaan untuk bisa memberikan pelayanan yang lebih luas kepada pemustaka tanpa harus bertatap muka. Perkembangan teknologi informasi ini pula yang mendasari lahirnya media sosial yang saat sekarang ini telah mengubah pola perilaku komunikasi dari sebagian besar masyarakat, termasuk di dalamnya adalah pengguna perpustakaan. Adanya media sosial juga memberikan kemudahan bagi perpustakaan untuk memberikan pelayanan kepada penggunanya.

Dari data yang dikeluarkan oleh We Are Social tentang Digital Report 2018, diketahui bahwa pada bulan Januari 2018, dari 265,4 juta penduduk Indonesia, 132,7 juta penduduk Indonesia telah menggunakan internet dalam aktifitas sehari-harinya. Data lain juga menyebutkan 130 juta penduduk Indonesia tercatat sebagai pengguna aktif media sosial. Dalam data yang dikeluarkan oleh We Are Social juga menyebutkan, Youtube, Facebook dan WhatsApp sebagai platform media sosial yang paling sering digunakan oleh pengguna media sosial yang ada di Indonesia.

Dari data-data tersebut dapat diketahui bahwa saat ini media sosial telah menjadi gaya hidup dari sebagian masyarakat Indonesia dan perpustakaan sebagai salah satu institusi yang memberikan layanan informasi dan penyedia sumber informasi bagi pemustaka harus bisa menyesuaikan diri dengan keadaan yang ada saat ini.

Di samping adanya fenomena penggunaan media sosial sebagaimana tersebut di atas, dalam beberapa penelitian tentang penggunaan media sosial di perpustakaan ditemukan bahwa saat ini telah mulai tumbuh kesadaran dari perpustakaan untuk menggunakan media sosial sebagai bentuk inovasi dari layanan yang diberikan oleh perpustakaan kepada pemustakanya.

Pada penelitian yang dilakukan oleh Dowd pada tahun 2013 dan penelitian yang dilakukan oleh Taylor dan Francis Group pada tahun 2014 disebutkan bahwa dari $86 \%$ perpustakaan yang menjadi obyek penelitiannya telah menggunakan media sosial sebagai salah media layanan kepada 
pemustakanya, dan 30\% perpustakaan melakukan aktifitas posting setiap harinya di media sosial untuk menginformasikan kegiatan-kegiatan yang ada di perpustakaannya. Dalam penelitian yang lain yang dilakukan oleh Garofalo pada tahun 2013 kepada para mahasiswa menyebutkan bahwa pentingnya perpustakaan untuk menggunakan media sosial sebagai salah satu "alat" untuk menginformasikan kegiatan-kegiatan yang ada di perpustakaan.

\section{Tinjauan Pustaka}

Andreas Kaplan dan Michael Haenlein mendefinisikan "media sosial sebagai sebuah kelompok aplikasi berbasis internet yang membangun di atas dasar ideologi dan teknologi Web 2.0 dan memungkinkan penciptaan pertukaran user-generated content." (Kaplan \& Haenlein)

Menurut Meredith G Farkas (Meredith, 2007)“media sosial secara umum dalam pemanfaatannya memiliki 9 karakteristik yang dirinci sebagaimana berikut :

\section{Kemudahan dalam membuat dan membagikan isi berita / deskripsi}

Setiap orang yang menggunakan media sosial dapat dengan mudah menuliskan / membuat isi dari berita atau deskripsi dari produk atau jasa yang hendak dibagi

\section{Kolaborasi online}

Seseorang dapat dengan mudah saling berkerjasama untuk menuliskan sebuah materi yang akan mereka bagikan. Contoh dari bentuk ini adalah Wikipedia

\section{Percakapan dapat dibagikan secara real time}

Bagi pengguna media sosial yang menggunakan media sosial dalam bentuk percakapan, dapat secara langsung menerima atau membalas percakapan dari lawan bicara tanpa menggu jeda yang cukup lama.

\section{Masyarakat berkembang dari bawah ke atas}

Media sosial membantu kita membangun berbagai jenis masyarakat. Saat ini banyak masyarakat online yang tidak lagi memerlukan forum, papan buletinatau e-mail. Percakapan bisa berlangsung di wiki, di bagian komentar blog, atau melalui berbagai aplikasi dari media sosial. Komunitas ini terbentuk karena adanya beberapa orang yang menggunakan media sosial yang serta memiliki hobi atau peminatan yang sama di antara satu dengan yang lainnya. 


\section{Memanfaatkan kebijaksanaan dari banyak orang.}

Media tidak hanya bisa sebagai alat untuk berkomunikasi, berkolaborasi serta alat untuk membangun sebuah komunitas, tetapi dengan media sosial, sesorang akan bisa mendapatkan banyak pengetahuan serta bisa banyak belajar dari perilaku orang-orang yang berpartipasi dalam media sosial tersebut.

\section{Transparan}

Dengan media sosial, perpustakaan dapat terhubung secara pribadi dengan pemustakanya dan itu dapat diketahui oleh banyak orang. Tidak ada hal yang ditutup-tutupi dengan menggunakan media sosial.

\section{Personalisasi}

Dengan teknologi RSS telah memungkinkan seseorang untuk berlangganan secara tertentu sesuai dengan topik yang diinginkannya.

\section{Portabilitas}

Semua media sosial selalu terhubung dengan internet, sehingga memungkinkan seseorang untuk mengaksesnya selama 24 jam penuh tanpa terkena hambatan ruang dan waktu, dengan syarat orang tersebut terhubung dengan jaringan internet.

\section{Mengatasi hambatan jarak dan waktu}

Adanya media sosial yang terhubung dalam jaraingan internet, memungkin sesorang untuk bisa berkomunikasi dari mana pun dia berada, serta bisa berkomunikasi kapan pun tanpa dibatasi oleh waktu."

Dari sembilan karakteristik yang telah ditampilkan di atas, dapat sedikit banyak mengubah pandangan sebuah perpustakan untuk membangun komunikasi dengan pemustakanya. Komunikasi yang dahulunya hanya bisa terjadi secara tatap muka, kini dengan adanya media sosial, perpustakaan sebagai penyedia sumber informasi dapat berkomunikasi dengan pemustakanya tanpa harus berada dalam suatu ruang atau tempat yang sama.

Hai ini dimungkinkan karena media sosial tidak membatasi seseorang untuk berkomunikasi dalam ruang dan tempat yang sama.

Di samping sembilan karakteristik yang telah disampaikan di atas, menurut Gambel,M dan T.K Gambel (Gambel, 2002) "media sosial secara garis besar juga memiliki ciri-ciri sebagai berikut 
1. Pesan yang disampaikan tidak hanya untuk satu orang saja, tetapi pesan dapat disampaikan untuk beberapa orang secara bersamasama

2. Pesan yang disampaikan bebas tanpa harus melalui Gatekeeper

3. Pesan yang disampaikan memiliki kecenderungan lebih cepat dibandingkan dengan media yang lainnya.

4. Penerima pesan dapat menentukan waktu untuk berinteraksi.

Menurut Tim Pusat Humas Kementerian Perdagangan (RI, 2014) "media sosial memiliki kelebihan dibandingkan dengan media yang lainnya. Adapun kelebihan yang dimiliki adalah sebagai berikut :

1. Cepat, ringkas, padat dan sederhana

Bila kita lihat, dalam setiap produksi media konvensional membutuhkan ketrampilan khusus, standard yang baku serta memiliki kemampuan marketing yang unggul, Hal ini terkadang bisa menjadi kendala tersendiri bagi penggunanya. Di lain pihak, media sosial memiliki keunggulan lebih user friendly dibandingkan media yang lainnya.Seorang pengguna tidak memerlukan kemampuan khusus untuk bisa menjalankannya.

2. Menciptakan hubungan yang lebih intens

Media sosial memberikan kemungkinan adanya interaksi dua arah, yang mana pengirim pesan dapat secara langsung mendapatkan feedback dari penerima pesan tanpa jeda waktu yang lama. Hal ini sangatlah berbeda bila dibandingkan dengan media konvensional yang hanya memungkinkan seorang pengguna hanya berkomunikasi satu arah saja. Adanya interaksi dua arah inilah yang menjadikan media sosial bisa menciptakan hubungan yang intens antara penggunanya.

3. Jangkauan luas dan global

Media konvensional memamng ,memungkinkan untuk menjangkau secara global, tetapi untuk mewujudkan hal ini dibutuhkan biaya yang sangat besar untuk penyediaan infrastrukturnya. Dari segei penyampaian informasinya pun juga jauh lebih lama dibandingkan dengan komunikasi lewat media sosial. Seorang pengguna media sosial juga diberikan ruang untuk men-create target dari yang diinginkannya.

4. Kendali dan terukur 
Di dalam media sosial dengan sistem pelacakan (tracking) yang tersedia, memungkinkan seorang pengguna untuk mengendalikan dan mengukur efektivitas informasi yang disampaikan melalui feedback yang datang dari penerima informasi tersebut. “

\section{B. HASIL DAN PEMBAHASAN}

\section{Pemanfaatan Media Sosial di Perpustakaan Perguruan Tinggi}

Sebagaimana telah dijelaskan di atas, media sosial memiliki kemampuan yang lebih dibandingkan media yang lain untuk membantu perpustakaan dalam meningkatkan kualitas layanan yang akan diberikan kepada pemustakanya. Menurut Sirly, secara garis besar media sosial dapat dimanfaatkan untuk mempromosikan keberadaan perpustakaan atau untuk mengenalkan / mempromosikan koleksi yang ada di perpustakaan kepada penggunanya. Melalui media sosial, akses untuk mempromosikan kedua hal tersebut dapat dilakukan lebih cepat dan efisien. (Sirly, 2014)

Media sosial bagi pengguna / pemustaka juga memberikan kemudahan untuk mengakses data atau segala bentuk informasi yang ada di perpustakaan. Media sosial juga memberikan manfaat sebagai berikut.

1. Sebagai Tempat Berinteraksi atau Berdiskusi dengan Pustakawan atau Pemustaka

Media sosial dapat memberikan manfaat untuk berinteraksi atau berdiskusi dengan pustakawan atau pemustaka yang lain tanpa harus saling bertatap muka saru dengan yang lainnya. Hal ini dapat dilakukan melalui forum atau group diskusi yang dibuat dengan memanfaatkan fitur-fitur yang disediakan oleh beberapa aplikasi media sosial. Adapun aplikasi yang dapat digunakan adalah whatsapp, line, telegram, BBM atau aplikasi media sosial lainnya yang berbasis percakapan (chatting)

2. Sebagai Media Penunjang untuk Menyampaikan Informasi kepada Pemustaka

Media sosial dapat pula dimanfaatkan untuk menyampaikan informasi-informasi yang ada di Perpustakaan kepada pemustaka/pengguna perpustakaan. Informasi tersebut dapat berupa informasi tentang koleksi-koleksi yang ada di perpustakaan atau informasi tentang layanan-layanan yang ada di perpustakaan. Informasi tersebut dapat dilakukan secara personal, orang per orang atau dapat dilakukan secara serentak kepada beberapa pemustaka 
(brocast message). Penyampaian informasi dapat dilakukan secara interaksi langsung, yang mana pengirim pesan dapat secara langsung mendapatkan respon dari penerimanya. Aplikasi media sosial yang dapat digunakan untuk penyampaian informasi seperti ini diantaranya adalah whatsapp, telegram, line, BBM atau aplikasi media sosial lainnya yang berbasis percakapan (chatting). Aplikasi media sosial lainnya yang dapat digunakan/dimanfaatkan untuk menyampaikan informasi kepada pemustaka adalah Instagram, Facebook dan Google Plus (G+).

Media sosial bagi perpustakaan juga dapat mendorong para pustakawan untuk berinovasi untuk menciptakan bentuk-bentuk layanan baru yang belum ada sebelumnya di perpustakaan. Media sosial juga dapat meningkatkan kreatifitas seorang pustakawan untuk menciptakan layananlayanan baru yang belum ada di perpustakaan sebelumnya. Yang kemudian menjadi sebuah pertanyaan, inovasi, strategi komunikasi dan kreatifitas seperti apa yang dapat dilakukan oleh pustakawan yang dapat didukung oleh media sosial?

Untuk memberikan informasi tetang layanan yang ada di perpustakaan, seorang pustakawan tidak hanya bisa menginformasikannya dalam bentuk tulisan saja, tetapi juga dapat dilakukan dengan menginformasikannya lewat gambar bergerak yang dilengkapi dengan suara (audio visual). Informasi tersebut dapat berupa video tutorial tentang bagaimana cara memanfaatkan layanan-layanan di perpustakaan atau informasi-informasi yang lainnya. Informasi-informasi yang telah dibuat tersebut, dapat dibagikan melalui beberapa media sosial yang menyediakan fitur-fitur untuk berbagi video. Aplikasi media sosial yang dapat digunakan untuk hal tersebut diantaranya adalah youtube, instagram atau facebook.

Aplikasi media sosial yang berbasis percakapan (chatting) seperti whatsapp, telegram, line atau BBM juga dapat digunakan untuk berinovasi dalam layanan yang ada di perpustakaan. Dengan aplikasi tersebut, perpustakaan dapat menyediakan layanan penelusuran informasi (information retreival service) untuk penggunanya. Seorang pengguna perpustakaan (pemustaka) dapat bertanya tentang koleksi-koleksi yang ada di perpustakaan melalui account media sosial yang dimiliki perpustakaan tanpa harus pengguna tersebut bertemu muka atau berada dalam satu tempat yang sama.

Dalam pemanfaatan media sosial di perpustakaan, tentunya memiliki beberapa tantangan dan kendala yang dihadapi. Adapun kendala-kendala yang sering dihadapi diantaranya adalah sebagai berikut : 
1. Adanya komitmen dari pengelola perpustakaan yang masih kurang

2. Diperlukannya keahlian teknologi bagi pustakawan untuk mengoperasikan media sosial tersebut

3. Adanya perbedaan minat serta kemampuan yang berbeda-beda antar staf perpustakaan dalam mengoperasikan media sosial tersebut.

4. Keterbatasan anggaran yang dimiliki oleh perpustakaan untuk berkelanjutannya pengoperasionalan media sosial.

5. Permasalahan HAKI dalam penggunaan content yang dibagikan kepada pengguna di media sosial.

6. Keterbatasan sarana prasarana yang dimiliki oleh perpustakaan untuk mengoperasikan media sosial tersebut, contoh : koneksi internet.

Di samping beberapa kendala di atas, beberapa perpustakaan yang telah menggunakan media sosial sering mengeluhkan kurangnya optimalnya penggunaan media sosial. Kurang optimalnya penggunaan media sosial ini dapat dilihat dari kurangnya respon dari pemustaka atau calon pemustaka dari perpustakaan tersebut.

Kurang responnya pemustaka atau calon pemustaka dapat disebabkan karena beberapa hal, seperti kurang menariknya content yang ditampilkan di account media sosial dari perpustakaan atau adanya ketidaktahuan dari pemustaka atau calon pemustaka terhadap account media sosial yang dimiliki oleh perpustakaan.

Ada beberapa hal yang dapat dilakukan untuk mengatasi kendalakendala yang dihadapi tersebut. Di antaranya adalah sebagai berikut :

1. Tampilkan Gambar dan Deskripsi yang Menarik

Gambar dan dekripsi pada sebuah account media sosial memiliki peran yang sangat penting. Karena dengan gambar menarik akan bisa mengundang seseorang untuk melihat account media sosial kita lebih detail. Gambar yang menarik adalah gambar yang bisa "bercerita" dan bisa memberikan pemahaman kepada orang yang melihatnya secara sekilas. Akan lebih menarik lagi apabila ditampilkan gambar dalam bentuk bergerak atau gambar hidup. Deskripsi yang jelas juga dapat memberikan "bantuan" seseorang untuk lebih memahami gambar yang ditampilkan di account media sosial dari perpustakaan tersebut. 
2. Pilih Waktu yang Tepat untuk men-Share Informasi

Pemilihan waktu terkadang juga memiliki pengaruh terhadap kemungkinan informasi yang kita bagikan lewat media sosial bisa terbaca/dilihat oleh pengguna media sosial media lain yang menjadi "teman" atau pengikut (follower) dari account media sosial perpustakaan kita. Waktu yang disarankan untuk membagi informasi adalah pada pukul $06.00-08.00$, pada saat rehat siang, pukul 11.00-13.00 dan setelah pukul 18.00. Waktu-waktu yang disebutkan adalah waktu-waktu yang memungkinkan seseorang untuk membuka account media sosial yang mereka miliki.

3. Gunakan Hashtag

Hashtag digunakan sebagai "alat-bantu" bagi pengguna media sosial untuk menemukan account media sosial yang mereka butuhkan. Penggunaan hashtag yang tepat dapat membantu pengguna media sosial lain untuk menemukan account dari perpustakaan kita

4. Iklankan Media Sosial Kita

Cara yang mungkin bisa dilakukan agar account media sosial bisa terbaca lebih banyak pengguna media sosial lain adalah dengan mengiklankan account media sosial dari perpustakaan kita. Beberapa aplikasi media sosial menyediakan fitur yang dapat digunakan untuk mengiklankan account media sosial yang dimiliki. Sebagai contoh adalah Instagram dengan fitur Instagram Bisnisnya dan Facebook dengan fitur FB Ads nya.

\section{KESIMPULAN}

Dari apa yang telah diuraikan di atas dapat diketahui, seberapa pentingya manfaat media sosial untuk membantu mengkomunikasikan segala bentuk informasi yang ada di perpustakaan. Baik itu informasi tentang kegiatan, layanan yang ada atau informasi yang berkaitan dengan koleksi yang ada di perpustakaan.

Agar penggunaan media sosial di perpustakaan dapat lebih optimal, terdapat beberapa hal yang harus diperhatikan. Optimalisasi penggunaan media sosial di perpustakan perlu dilakukan agar segala informasi yang ada dapat tersampaikan dengan baik. 
36 | RM Endhar Priyo Utomo : Pemanfaatan Sosial Media...

\section{DAFTAR RUJUKAN}

Anwar, A. (2016). Pemanfaatan media sosial dalam pelayanan referensi 2.0 di Indonesia. Jurnal Ilmu Perpustakaan, Informasi, dan Kearsipan Khizanah Al-Hikmah, 57 - 64.

Gambel, M. (2002). Communication Work. Boston: McGraww Hill.

Kaplan, A., \& Haenlein, M. (2010). Users of the world, unite! The challenges and opportunities of Social Media. Business Horizons, 59 - 68.

Meredith, G. (2007).

RI, T. (2014). Panduan Optimalisasi Media Sosial Untuk Kementerian Perdagangan. Jakarta: Pusat Hubungan Masyarakat Kementerian Perdagangan RI.

Sirly. (2014). 